\title{
Impact of heavy metal contamination on oxidative stress of Eisenia andrei and bacterial community structure in Tunisian mine soil
}

\author{
Iteb Boughattas $^{1}$ - Sabrine Hattab ${ }^{2}$ - Hamadi Boussetta ${ }^{1}$ - Mohamed Banni ${ }^{1,3}$. \\ Elisabeth Navarro ${ }^{4,5}$
}

Received: 10 November 2016 / Accepted: 1 June 2017

(C) Springer-Verlag GmbH Germany 2017

\begin{abstract}
The aims of this work were firstly to study the effect of heavy metal-polluted soils from Tunisian mine on earthworm biochemical biomarkers and on bacterial communities and therefore to analyze the interaction between earth worms and bacterial communities in these contaminated soils. For this purpose, we had introduced earthworm Eisenia andrei in six soils: one from mine spoils and five from agricultural soils, establishing a gradient of contamination. The response of worms to the presence of heavy metal was analyzed at the biochemical and transcriptional levels. In a second time, the impact of worm on bacterial community structure was investigated using automated ribosomal intergenic spacer analysis (ARISA) fingerprinting. An impact of heavy metalcontaminated soils on the oxidative status of $E$. andrei was observed, but this effect was dependent of the level of heavy metal contamination. Moreover, our results demonstrate that the introduction of earthworms $E$. andrei has an impact on
\end{abstract}

Responsible editor: Philippe Garrigues

Mohamed Banni

m_banni@yahoo.fr

1 Laboratory of Biochemistry and Environmental Toxicology, ISA Chott-Mariem, 4042 Sousse, Tunisia

2 Regional Research Centre in Horticulture and Organic Agriculture, Chott-Mariem, 4042 Sousse, Tunisia

3 Department of Sciences and Technological Innovation (DiSIT), University of Piemonte Orientale “A. Avogadro", V. le T. Michel 11, 15121 Alessandria, Italy

4 Laboratoire AMPERE Ecole Centrale de Lyon, 36, avenue Guy de Collongue, 69134 Ecully Cedex, France

5 IRD-UMR LSTM, Campus de Baillarguet, 34398 Montpellier, France bacterial community; however, the major change was observed in the less contaminated site. Furthermore, a significant correlation between earthworm oxidative status biomarkers and bacterial community structure was observed, mainly in the mine spoils. Therefore, we contribute to a better understanding of the relationships between epigenic earthworms and bacterial communities in heavy metal-contaminated soils.

Keywords Eisenia andrei · Oxidative stress · Heavy metals · Bacterial community

\section{Introduction}

Heavy metals are naturally occurring elements that have a high atomic weight and a density at least five times greater than that of water (Fergusson 1990). This group includes both biologically essential elements such as cobalt (Co), copper $(\mathrm{Cu})$, chronium $(\mathrm{Cr})$, manganese $(\mathrm{Mn})$, and zinc $(\mathrm{Zn})$ and nonessential elements such as cadmium $(\mathrm{Cd})$, lead $(\mathrm{Pb})$, and mercury (Hg). The essential heavy metals carry on biochemical and physiological functions in plants, animals, and humans. Since they are essential constituents of several key enzymes, they are required in low concentrations since (Adriano 2001; Bradl 2002). Nevertheless, as nonessential elements, they are toxic to plants, animal, and/or human at very high concentrations. Indeed, an excess amount of heavy metals produces cellular and tissue damage leading to a variety of adverse effects and human diseases (Chang et al. 1996; Wang and Shi 2001).

Most of the time, soil contaminations by heavy metals occurred after human activities like metal manufacture and mining industries with storage, disposal, and transportation problems (Çelo et al. 1999; Zhang et al. 2005). Due to heavy metal toxicity, soil contamination is posing significant threats to the 
environment and public health. At excessive concentrations in soils, heavy metals are known to be toxic to microorganisms. The pollutants alter the structure and metabolic activity of soil microbial communities (Gong et al. 2002; Kenarova and Radeva 2010; Kenarova et al. 2014). The effects of heavy metal depend on the metal, on the level of contamination, and on the soil type, which can support microorganisms to overcome the stress and/or modulate the behavior of pollutants including their bioavailability and toxicity (Kozdrój and van Elsas 2001; Vig et al. 2003; Ramakrishnan et al. 2011). The toxicity of heavy metal is generally assessed by determining the total metal content of soil, but from a biological and agricultural point of view, the bioavailable metal content, depending of metal speciation, is more. Speciation is defined as the identification and quantification of the different, defined species, forms, or phases in which an element occurs and is essentially a function of the mineralogy and chemistry of the soil sample examined (Cottenie et al. 1980; Tack and Verloo 1995).

Several million tons of $\mathrm{Pb}-\mathrm{Zn}$ ore-processing wastes were generated in northern Tunisia during the last century and then abandoned as tailing piles in several localities, without concern for environmental issues. These mine spoils are also adjacent to villages and farmlands. Mediterranean climate promotes spreading of metallic contamination toward air and soils and lets their dissimilation from mine spoils to olive tree cultures (Souissi et al. 2013; Ghorbel et al. 2014). The Djebel Ressas mining site is considered as a representative site of $\mathrm{Pb}$ $\mathrm{Zn}-\mathrm{Cd}$ mining sites from northern Tunisia (Ghorbel et al. 2014). It is located $30 \mathrm{~km}$ south of Tunis where mining activity was processed during almost 70 years (1880-1956). Mining activities in Djebel Ressas generated important quantities of spoils. The old mining town is located very close to mine spoils that are highly concentrated in $\mathrm{Pb}, \mathrm{Zn}$, and $\mathrm{Cd}$.

Earthworms, as an essential component of the soil fauna, ingest large amounts of soil and have the potential to modify the environment of soil microorganisms by modifying edaphic parameters such as soil structure and pH (Lavelle 1997). Actively feeding earthworms have an influence on the spatial distribution of microorganisms and may change the biomass, activity, and structure of microbial communities (Brown 1995; Egert et al. 2004; Orazova et al. 2005; Aira et al. 2010; Nechitaylo et al. 2010; Bernard et al. 2012; Koubova et al. 2015). Previous studies indicate that the interaction between earthworms and soil microflora is dependent of the ecological group of earthworm (anecic, endogeic, and epigenic), enzymatic and bacterial composition of earthworm gut, and earthworm feeding habitat (Thakuria et al. 2010; Bernard et al. 2012; Koubova et al. 2015). However, the basic mechanisms of how earthworms affect microbial populations and factors influencing the interaction between worms and microorganisms are not yet well understood. Although there is a large body of literature on the impact of earthworms on microorganisms in soils, only a few studies have studied this impact in heavy metal-contaminated soils. However, it has been demonstrated that earthworms significantly stimulate microbial activity and increased the abundance of soil cultivable fungi as well as the potential metabolic bacterial abilities in metal-contaminated soils (Kristufek et al. 1992; Jusselme et al. 2015).

In order to assess the potential ecological risk of heavy metals on soil ecosystem, earthworms have been used as model organisms and their importance in testing its adverse effects has been recognized by various environmental organizations (OECD 1984). A range of biomarkers has been developed in recent years to evaluate organism stress response to individual toxic ( $\mathrm{Hu}$ et al. 2010; Moore et al. 2004; Sforzini et al. 2015). Excess ROS may lead to oxidative stress, lipid peroxidation, and cell death. To fight against oxidative stress and lipid peroxidation, many endogenous antioxidant enzymes, such as catalase (CAT), superoxide dismutase (SOD), and glutathione S-transferase (GST), will eliminate excess ROS and inhibit their deleterious effects. Therefore, changes in these biomarkers may indirectly indicate the toxic effects of contaminants on earthworms (Schreck et al. 2008).

Although effects at the biomarker level may be indicative of disturbances at higher levels of populations or communities (Weeks et al. 2004), only a few examples are available of such a link between biomarker level responses and effects on the functioning of earthworms in ecosystems, in particular the effects on structural diversity of bacterial communities in heavy metal-contaminated soils.

The aim of this work was to investigate the effect of heavy metals on soil functioning. For this purpose, earthworm Eisenia andrei, exposed to a gradient of polymetallic contaminated soils, were tested for their oxidative stress biomarker response. In parallel, RISA fingerprinting was used to determine change in bacterial community structures after passage in earthworm gut. We hypothesized that the earthworm's oxidative status modulates their effect on bacterial communities in heavy metal-contaminated soils.

\section{Material and methods}

\section{Sites and sample collection}

Six soils were considered for this study (A-F) ranging from the highest contaminated (A) to the lowest contaminated soil (F) considered as the relative control site (Fig. 1). A gradient for these sites is established based on their heavy metal concentration (Table 1). On the other hand, the gradient starts with a mine spoil site (A) while the other sites are located in agriculture area 
Fig. 1 Map of Tunisia sites where soils were collected in Djebel Ressas mining region. S6 $\left(36^{\circ} 36^{\prime} 57.81^{\prime \prime} \mathrm{N} ; 10^{\circ} 19\right.$, $404.88^{\prime \prime}$ E) (reference site), S5 $\left(36^{\circ} 36^{\prime} 35.87^{\prime \prime} \mathrm{N} ; 10^{\circ} 19^{\prime} 04.88^{\prime \prime}\right.$ E), S4 (36 $36^{\circ} 57.76^{\prime \prime} \mathrm{N} ; 10^{\circ} 17^{\prime}$ $\left.14.53^{\prime \prime} \mathrm{E}\right), \mathrm{S} 3$ ( $36^{\circ} 38^{\prime} 59.64^{\prime \prime} \mathrm{N}$; $\left.10^{\circ} 18^{\prime} 07.63^{\prime \prime} \mathrm{E}\right), \mathrm{S} 2\left(36^{\circ} 38^{\prime}\right.$ $\left.18.79^{\prime \prime} \mathrm{N} ; 10^{\circ} 18,442.44^{\prime \prime} \mathrm{E}\right)$, and $\mathrm{S} 1\left(36^{\circ} 37^{\prime} 05.85^{\prime \prime} \mathrm{N} ; 10^{\circ} 19^{\prime}\right.$ $\left.10.37^{\prime \prime} \mathrm{E}\right)$

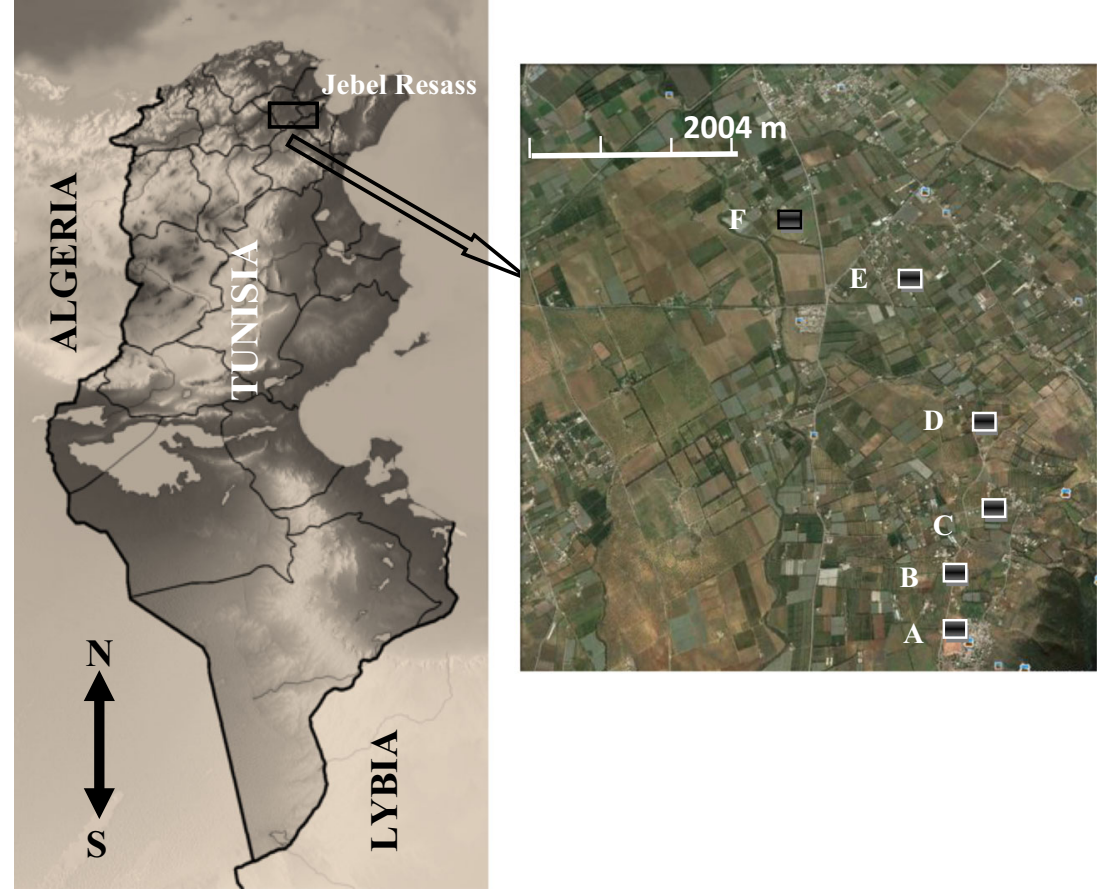

(olive tree culture). Soil from each site was taken from a depth $0-30 \mathrm{~cm}$ where Ghorbel et al. (2014) reported that the highest heavy metal contamination throws the soil profile. Each of the samples represented a combination of five subsamples from the center and the four corners of a square sampling grid. Soil subsamples at each location were homogenized, combined, and transferred to clean containers. In the laboratory, soils were air-dried and sieved through a $2-\mathrm{mm}$ screen and they were conserved until use. Soils ranged from loam to clay soils as already described by Ghorbel et al. (2014).

\section{Soil analysis}

Soil $\mathrm{pH}$ was measured in soil suspension obtained by shaking $1 \mathrm{~g}$ of soil in water (soil/ $\mathrm{H}_{2} \mathrm{O}$ ratio $1: 2.5$ ) for $1 \mathrm{~h}$ and then by using a $\mathrm{pH}$ meter (Metrohm 744). Available $\mathrm{P}$ in soil was extracted by sodium bicarbonate and determined using the molybdenum blue method (Olsen et al. 1954). Available K in soil was extracted by ammonium acetate and determined by flame photometry (Carson 1980). $\mathrm{CaCl}_{2}$ was determinate using the Rayment and Higginson method (Rayment and Higginson 1992). For organic carbon analysis, $25 \mathrm{mg}$ of soil

Table 1 Characteristics of soil samples collected from Djebel Ressas sites

\begin{tabular}{|c|c|c|c|c|c|c|}
\hline Parameters & Site A & Site B & Site C & Site D & Site E & Site F \\
\hline Land use & Mine spoils & Olive tree & Olive tree & Olive tree & Olive tree & Olive tree \\
\hline $\mathrm{pH}$ & $8.24 \pm 0.07$ & $8.16 \pm 0.03$ & $7.95 \pm 0.03$ & $7.97 \pm 0.02$ & $7.85 \pm 0.08$ & $7.81 \pm 0.04$ \\
\hline Organic matter $(\%)$ & $1.70 \pm 0.14$ & $2.41 \pm 0.06$ & $2.53 \pm 0.10$ & $2.59 \pm 0.05$ & $2.71 \pm 0.10$ & $1.95 \pm 0.02$ \\
\hline $\mathrm{CaCO}_{3}(\%)$ & $15.07 \pm 0.95$ & $13.07 \pm 1.00$ & $19.03 \pm 2.53$ & $10.07 \pm 0.15$ & $16.10 \pm 0.60$ & $18.07 \pm 0.47$ \\
\hline $\mathrm{P}_{2} \mathrm{O}_{5}(\mathrm{ppm})$ & $13.02 \pm 1.78$ & $30.12 \pm 1.08$ & $56.03 \pm 1.36$ & $24.07 \pm 0.85$ & $11.17 \pm 1.01$ & $39.97 \pm 0.99$ \\
\hline $\mathrm{K}_{2} \mathrm{O}$ (ppm) & $49.23 \pm 3.95$ & $141.03 \pm 4.88$ & $296.00 \pm 9.73$ & $174.03 \pm 9.18$ & $357.06 \pm 5.80$ & $291.00 \pm 9.31$ \\
\hline $\mathrm{MgO}(\mathrm{ppm})$ & $64.13 \pm 4.34$ & $56.03 \pm 4.00$ & $140.07 \pm 9.94$ & $88.00 \pm 2.25$ & $237.03 \pm 7.13$ & $434.00 \pm 9.36$ \\
\hline $\mathrm{Cu}(\mathrm{ppm})$ & $14.25 \pm 2.18$ & $9.81 \pm 0.78$ & $4.58 \pm 0.27$ & $1.27 \pm 0.11$ & $1.78 \pm 0.16$ & $1.98 \pm 0.14$ \\
\hline $\mathrm{Fe}(\mathrm{ppm})$ & $1.28 \pm 0.44$ & $1.75 \pm 0.05$ & $1.31 \pm 0.11$ & $1.25 \pm 0.24$ & $1.53 \pm 0.11$ & $2.6 \pm 0.11$ \\
\hline $\mathrm{Mn}(\mathrm{ppm})$ & $306 \pm 21.40$ & $285 \pm 15.12$ & $186 \pm 12.35$ & $217 \pm 17.54$ & $244 \pm 31.21$ & $413 \pm 31.25$ \\
\hline $\mathrm{Zn}(\mathrm{ppm})$ & $42,400 \pm 245$ & $6690 \pm 452$ & $2550 \pm 254$ & $753 \pm 54$ & $323 \pm 21$ & $174 \pm 12$ \\
\hline $\mathrm{Pb}(\mathrm{ppm})$ & $14,500 \pm 278$ & $2490 \pm 321$ & $985 \pm 87$ & $374 \pm 44$ & $173 \pm 12$ & $116 \pm 15$ \\
\hline $\mathrm{Cd}(\mathrm{ppm})$ & $184.00 \pm 10.25$ & $27.10 \pm 2.31$ & $13.20 \pm 1.45$ & $1.59 \pm 0.24$ & $1.54 \pm 0.09$ & $0.67 \pm 0.01$ \\
\hline
\end{tabular}


crushed at $250 \mathrm{~lm}$ was decarbonated with hydrochloric acid and then analyzed with a CHN analyzer according ISO 10694 procedure. Organic matter content was calculated by multiplying organic carbon concentration by 1.72. Mg was determined digestion using the Hossner method.

\section{Experimental procedure}

The experiment was under controlled conditions, conducted as a completely randomized factorial design with three factors. The first factor is the levels of contamination presented by the six soils, the second factor had two periods of exposition: 7 and 14 days, and the third factor had two levels (introduction or not of $E$. andrei earthworms). Three replicates per treatment were carried out, making a total of 72 pots.

Earthworms, E. andrei (Oligochaeta, Lumbricidae), used in this study were obtained from the culture maintained in our laboratory with horse dung as substrate and food. Healthy adult animals, more than 2 months in age with a bodyweight of approximately $0.5 \mathrm{~g}$ and obvious clitellum, were chosen.

One kilogram of dried and sieved $(<2 \mathrm{~mm})$ soil was placed in polyethylene pots. The soil was then uniformly rewetted to moisture content of $60 \%$ using distilled water. This was maintained through the experience. Twenty earthworms were introduced into half pots, the other half being without worm. Each pot was covered with fine nylon to prevent soil loss and stop earthworm escape. The pots were incubated at $25^{\circ} \mathrm{C}$. At the end of the exposure period, for each treatment, ten earthworms were considered for the biochemical essay. Additional, four pools of earthworms per treatment are placed in RNAlater preserving solution for molecular analysis. For microbiological and physicochemical analyses, soils (three replicates per treatment) were conserved at ambient temperature until their analyses.

\section{Earthworm analyses}

\section{Biochemical analyses}

Gut-cleaned earthworms $(0.5-1 \mathrm{~g} ; n=10)$ were homogenized in a glass homogenizer in ice-cold extraction buffer ( $\mathrm{pH} 7.5)$ containing $250 \mathrm{mmol} \mathrm{L}^{-1}$ sucrose, $50 \mathrm{mmol} \mathrm{L}^{-1}$ Tris- $\mathrm{HCl}$, $1 \mathrm{mmol} \mathrm{L}^{-1}$ EDTA, and $1 \mathrm{mmol} \mathrm{L}^{-1}$ DTT at a $1 / 4 w / v$ ratio. The homogenates were centrifuged at $9000 \mathrm{~g}$ for $25 \mathrm{~min}$ to generate the $\mathrm{S} 9$ fraction. After centrifugation, the supernatants were collected and stored at $80{ }^{\circ} \mathrm{C}$ until analysis. All procedures were carried out at $4{ }^{\circ} \mathrm{C}$.

Proteins in the S9 fraction were quantified according to the Bradford method (Bradford 1976) using Coomassie Blue reagent.

The catalase (CAT) activity was determined according to the Claiborne method (Claiborne 1985). The reaction mixture had a final volume of $1 \mathrm{~mL}$ and contained $0.78 \mathrm{~mL} 0.1 \mathrm{M}$ phosphate buffer ( $\mathrm{pH} 7.5$ ) and $0.2 \mathrm{~mL} 0.5 \mathrm{mM} \mathrm{H}_{2} \mathrm{O}_{2}$. After
$30 \mathrm{~s}$ of preincubation, the reaction was started by the addition of $0.02 \mathrm{~mL}$ of the $\mathrm{S} 9$ solution containing the CAT fractions. CAT activity was evaluated by kinetic measurement at $20{ }^{\circ} \mathrm{C}$ using a Jenway 6105 spectrophotometer $(\lambda=240 \mathrm{~nm})$. The results were expressed as millimoles of hydrogen peroxide transformed per minute and per milligram protein.

The glutathione S-transferase (GST) activity was measured in DG cytosol by the method of Habig et al. (1974) using $10 \mathrm{mg}$ of cytosolic protein, $1 \mathrm{mM}$ 1-chloro-2,4-dinitrobenzene (CDNB) (Sigma-Aldrich, Saint Louis, MO, USA), and $4 \mathrm{mM}$ glutathione (reduced form; GSH) in $100 \mathrm{mM}$ sodium phosphate buffer, $\mathrm{pH}$ substrate 7.5. GST activity was determined by kinetic measurement at $20{ }^{\circ} \mathrm{C}$ using a Jenway 6105 spectrophotometer $(\lambda=340 \mathrm{~nm})$. The results were expressed as nanomoles GSH-CDNB produced per minute and per milligram protein.

The total superoxide dismutase (SOD) activity was determined based on inhibition of the reduction of nitro blue tetrazolium (NBT) (Crouch et al. 1981), which was generated by $37.5 \mathrm{mM}$ hydroxylamine in alkaline solution. The assay was performed in $0.5 \mathrm{M}$ sodium carbonate buffer ( $\mathrm{pH} 10.2)$ with $2 \mathrm{mM}$ EDTA and a $10 \mu \mathrm{L}$ aliquot of the supernatant. The reduction of NBT by superoxide anion to blue formazan was measured at $560 \mathrm{~nm}$. The SOD activity was calculated as its ability to inhibit NBT reduction by $50 \%$ per minute and was expressed as units per milligram protein.

The activity of acetylcholinesterase activity (AChE) was determined according to the method of Ellman et al. (1961), using the Jenway 6105 spectrophotometer. The reaction medium included sodium phosphate buffer $(0.1 \mathrm{M}, \mathrm{pH}$ 7.2), DTNB (1.6 mM), AcSChI (156 mM), and sample (S9). Kinetics was recorded at $412 \mathrm{~nm}$, and the assay was carried out at $25{ }^{\circ} \mathrm{C}$. The enzymatic activity was expressed as nanomole of acetylthiocholine hydrolyzed per minute per milligram of protein, and for calculations, the absorption coefficient of $13.6 \times 10^{3} \mathrm{M}^{-1} \mathrm{~cm}^{-1}$ was used.

For malondialdehyde (MDA) determination, gut-cleaned earthworms $\left(0.5-1 \mathrm{~g} ; \mathrm{n}^{1} \frac{1}{410}\right)$ were homogenized in two volumes of buffer containing $20 \mathrm{mM}$ Tris- $\mathrm{HCl}(\mathrm{pH} \mathrm{7.4)}$ ) and $0.1 \%$ mercaptoethanol. The homogenate was centrifuged at $18,000 \mathrm{~g}$ at $4{ }^{\circ} \mathrm{C}$ for $20 \mathrm{~min}$. The MDA concentration was determined as described by Gerard-Monnier et al. (1998).

\section{Gene expression}

Total RNA was extracted from the worms using acid phenol/ chloroform precipitation according to Chomczynski and Sacchi (1987) using TRI reagent (Sigma-Aldrich). RNA was purified further by precipitation in the presence of $1.5 \mathrm{M}$ $\mathrm{LiCl}_{2}$, and the quality of each RNA preparation was confirmed by UV spectroscopy and TBE agarose gel electrophoresis in the presence of formamide. 
The abundance of the messenger RNA (mRNA) of the genes encoding CAT, cytosolic superoxide-dismutase, and glutathione-S-transferase was evaluated in multiplex TaqMan assays according to Negri et al. (2013) and Banni et al. (2011). Complementary DNA (cDNA) (25 ng RNA reverse-transcribed to cDNA) was amplified in a CFX384 Real-Time PCR detection system (Bio-Rad Laboratories) using iQTM Multiplex Power mix (Bio-Rad Laboratories) according to the manufacturer's instructions for the triplex protocol. All multiplex combinations accounted for the following dual fluorescence tags: 6-carboxyfluorescein/Black Hole (BH) 1, 6-carboxy-2',4,4',5',7,7'-hexachlorofluorescein/ $\mathrm{BH} 1$, and Texas Red/BH2. Briefly, cDNA was amplified in the presence of $1 \times$ iQTM Multiplex Power mix using $0.3 \mathrm{mM}$ of each primer and $0.1 \mathrm{mM}$ of each probe described in Table 2 (Hattab et al. 2015) (Table 1) in a final volume of $10 \mu \mathrm{L}$.

Relative expression data were geometrically normalized to 18S rRNA (AB558505.1), to an invariant actin isotype (DQ286722.1), and to ribosomal protein riboS13 (BB998368.1) (Tsyusko et al. 2012). A specific triplex TaqMan assay was developed to amplify $0.25 \mathrm{ng}$ of RNA reverse-transcribed to cDNA in the presence of $0.1 \mathrm{mM}$ of each dual-labeled probe (hexachlorofluorescein/BH1 for actin, Texas $\mathrm{Red} / \mathrm{BH} 2$ for $18 \mathrm{~S}$ rRNA, and Hex/BH2 for protein riboS13) plus 0.4 and $0.4 \mathrm{mM}$ of the forward and reverse primers (Table 1). For all TaqMan assays, the thermal protocol was as follows: $30 \mathrm{~s}$ at $95^{\circ} \mathrm{C}$, followed by 40 cycles of $10 \mathrm{~s}$ at $95^{\circ} \mathrm{C}$ and $20 \mathrm{~s}$ at $60^{\circ} \mathrm{C}$. qRT-PCR was performed with four biological replicates and three technical replicates (Banni et al. 2011). The normalized expression was then expressed as relative quantity of mRNA (relative expression) with respect to the control sample. Statistical analyses were performed on the group mean values using a random reallocation test (Pfaffl et al. 2002).

\section{ARISA analyses for bacterial community structure}

\section{DNA extraction}

DNA was extracted from $250 \mathrm{mg}$ of each soil sample, except soil from site A, using the PowerSoil@ DNA
Isolation Kit (MO BIO Laboratories, Carlsbad, USA) according to the manufacturer's instructions. For soil from site A, DNA was extracted using the PowerMax ${ }^{\circledR}$ Soil DNA Isolation Kit (MO BIO Laboratories, Carlsbad, USA) using $10 \mathrm{~g}$ of soil and according to the manufacturer's instructions. The extracted DNA was purified with NucleoTrap® Nucleic acid and protein purification kit (Macherey-Nagel, Hoerdt, France). DNA concentrations were determined on $1 \mu \mathrm{L}$ of extracted DNA with the high-sensitivity kit (Invitrogen, Fisher Scientific, Illkirch, France) on Qubit Fluorometer (Invitrogen).

\section{Amplification and analysis of the IGS}

The intergenic spacer (IGS) region between the small and large subunit rDNA genes was amplified using $1 \mathrm{ng}$ of DNA template and the universal primers: SD-Bact-1522bS-20 and LD-Bact-132-aA-18 (Ranjard et al. 2001). Amplifications were obtained using the Hot Start Mix RTG (GE Healthcare, Orsay, France). To the lyophilized material, $23 \mu \mathrm{L}$ of the primer solution $(0.8 \mu \mathrm{M}$ final $)$ and $2 \mu \mathrm{L}$ of tenfold diluted soil DNA (or water for the negative sample) were added. Amplification was performed as follows: preheating at $95^{\circ} \mathrm{C}$ for $2 \mathrm{~min}$, followed by $30 \mathrm{cy}$ cles: denaturation at $94{ }^{\circ} \mathrm{C}$ for $50 \mathrm{~s}$, annealing at $55^{\circ} \mathrm{C}$ for $50 \mathrm{~s}$, and extension at $68^{\circ} \mathrm{C}$ for $2 \mathrm{~min}$. A final extension step at $68{ }^{\circ} \mathrm{C}$ for 5 min preceded a cooling step at $10{ }^{\circ} \mathrm{C}$. Amplification profiles were checked on $1 \%$ agarose gel. Then, in order to eliminate inhibitors, PCR products were purified with the NucleoSpin Gel and PCR Clean-up kit (Macherey-Nagel).

RISA was performed with the 2100 Bioanalyzer (Agilent Technologies, USA), using the High Sensitivity DNA chip according to the manufacturer's recommendations. The 2100 Expert Agilent software determines peak sizes and areas based on data for internal size standards in each and an external ladder and converts fluorescence data into electrophoregrams. The data are exported in a .csv formats and then imported into the RISA Aligner program (Navarro et al. 2015), aligned, and normalized.

Table 2 QPCR primers and TaqMan probes

\begin{tabular}{llll}
\hline Gene name & Probe & Sense primer & Antisense primer \\
\hline 18S & CGCCGACAGAGTGCCATCGACGAA & AATTCCGATAACGAACGAGACTCT & GCCACTTGTCCCTCTAAGAAGTTA \\
$\beta$-Actin & AGTCCGGGCCATCCATCGTCCACA & GGATCAGCAAGCAGGAGTACG & TGGTCATTGATAATGGAGGCACTT \\
RiboS13 & TCGCATGGTGTCGCTCAGACCCGT & TCACAGATTGGTGTTATCCTTCGA & GCAAGACCCTTAGCCTTCAGG \\
SOD & ATCACCACGCAACACGGACACGGC & TTGGACTTGGATCGTTGGTCG & GGAGAAACGGACAGTGCCAG \\
GST & AGCGGAGTGCCTGACCACGACCTC & GGTGTCCGATAGAATTCCTGCTAT & CTCCAGACCATTGTCTACAGCTAA \\
CAT & TGCCTTGTCTCTTGCCGCCATCGT & CTCGATTTCGTCTTATTCTTCGCC & CTTGTATTCGTTGAGTTGCTCGG \\
\hline
\end{tabular}

From Hattab et al. (2015) 
The data are exported in .csv formats and then imported into the RISA Aligner program (Navarro et al. 2015), which aligned and normalized data.

\section{Statistical analyses}

Results for enzymatic activity and MDA content are presented as mean \pm SD of 10 samples. SPSS (version 21) was used for statistical analyses. The normality of the distribution was tested using the Shapiro-Wilk test. For multiple comparisons, a parametric one-way analysis of variance (ANOVA) was performed on data along with Tukey's test.

To compare successively evolution of earthworm biomarkers and RISA patterns, principal component analyses (PCAs) were performed using the R software and the package ADE4TkGUI (Thioulouse and Dray 2007).

In order to analyze the relationship between earthworm biomarkers and bacterial community structure, a coinertia analysis was performed. Coinertia analysis is a standard multivariate analysis technique that describes the relationship between two data tables (Doledec and Chessel 1994; Dray et al. 2003). In order to performed coinertia analysis, two PCAs were performed. The first one described the genetic structure of bacterial communities, and the second one described earthworm biomarkers. The PCA, coinertia analysis, and the Monte Carlo test, used to check the significance of the analysis were performed using the Ade4TkGUI software (Thioulouse and Dray 2007).

\section{Results}

\section{Soil analysis}

The physicochemical characteristics of soils sampled from Djebel Ressas mines are presented in Table 1. The soils $\mathrm{pH}$ was weakly basic with values ranging from $7.81 \pm 0.04$ to $8.24 \pm 0.07$. Potassium and phosphorus contents of soils were the lowest in the most contaminated soils (A), while the maximum concentration was observed in soils $\mathrm{C}$ and $\mathrm{E}$, respectively. The less contaminated soil (F) presents the highest magnesium content with a value of $434.00 \pm 9.36$, which is largely superior to the amount observed in the other sites. On the other hand, the soils sampled had a higher calcareous content since values ranged between $10.07 \pm 0.15$ and 19 . $03 \pm 2.53 \%$. Organic matter content of these soils ranked between $1.70 \pm 0.14$ and $2.71 \pm 0.10 \%$.

\section{Enzyme activity and MDA content in earthworms $E$. andrei exposed to heavy metal-contaminated soils}

No earthworm mortality was recorded during the experience. The activity of antioxidant enzymes, CAT, SOD, and GST, reported in Table 3 showed an increase of these activities in worms exposed to soils from sites B, C, D, and E in comparison to control soil (F) after the two periods of exposure, except for SOD activity in animals introduced to soils from site B. A significant decrease in CAT and SOD activity was occurred in animals exposed to soils from site A, contrary to GST activity where an enhancement was observed in the same

Table 3 SOD, CAT, GST, AChE activities, and MDA accumulation in E. andrei after 7 or 14 days of exposition to six heavy metal-contaminated soils from the Djebel Ressas site

\begin{tabular}{|c|c|c|c|c|c|c|}
\hline Site & Time (days) & $\begin{array}{l}\text { CAT } \\
\text { (nmol } \mathrm{min}^{-1} \mathrm{mg}^{-1} \text { protein) }\end{array}$ & $\begin{array}{l}\text { GST } \\
\text { (nmol } \min ^{-1} \mathrm{mg}^{-1} \text { protein) }\end{array}$ & $\begin{array}{l}\text { SOD } \\
\left(\mu \mathrm{gg}^{-1} \text { protein }\right)\end{array}$ & 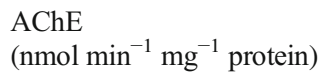 & $\begin{array}{l}\text { MDA } \\
\text { (nmol mg }{ }^{-1} \text { protein) }\end{array}$ \\
\hline \multirow[t]{2}{*}{ A } & 7 & $82.44 \pm 7.33$ & $152.14 \pm 14.82 *$ & $21.05 \pm 3.47 *$ & $52.14 \pm 7.21 *$ & $12.45 \pm 0.54^{*}$ \\
\hline & 14 & $60.25 \pm 9.47 * *, * * * \mathrm{c}$ & $122.75 \pm 13.77 * * *$ & $21.44 \pm 3.85^{* *}$ & $51.69 \pm 10.69^{* *}$ & $14.73 \pm 0.52 * *, * * *$ \\
\hline \multirow[t]{2}{*}{$\mathrm{B}$} & 7 & $208.54 \pm 11.65^{*}$ & $317.82 \pm 28.96^{*}$ & $34.19 \pm 5.24$ & $71.54 \pm 11.03 *$ & $10.47 \pm 0.83^{*}$ \\
\hline & 14 & $124.75 \pm 13.20$ & $379.25 \pm 29.47 * *, * * *$ & $32.40 \pm 5.63 * *$ & $62.84 \pm 8.36^{* *}$ & $11.28 \pm 0.81 * *, * * *$ \\
\hline \multirow[t]{2}{*}{$\mathrm{C}$} & 7 & $222.96 \pm 18.64 *$ & $314.25 \pm 25.89 *$ & $87.18 \pm 6.44^{*}$ & $85.86 \pm 9.86^{*}$ & $8.12 \pm 0.87 *$ \\
\hline & 14 & $168.89 \pm 14.94 * *, * * *$ & $389.45 \pm 22.34 * *, * * *$ & $68.96 \pm 5.23 * *, * * *$ & $74.41 \pm 8.30 * * * * * *$ & $8.98 \pm 0.98 * *$ \\
\hline \multirow[t]{2}{*}{$\mathrm{D}$} & 7 & $175.52 \pm 19.59^{*}$ & $289.14 \pm 29.36^{*}$ & $69.33 \pm 7.45^{*}$ & $102.85 \pm 9.94$ & $6.79 \pm 0.73^{*}$ \\
\hline & 14 & $186.89 \pm 20.96^{* *}$ & $317.44 \pm 28.44 * *$ & $62.78 \pm 6.88 * * \cdot * * *$ & $97.48 \pm 6.59$ & $7.12 \pm 1.13 * *$ \\
\hline \multirow[t]{2}{*}{$\mathrm{E}$} & 7 & $142.46 \pm 8.80 * ; * * *$ & $145.05 \pm 10.58 *$ & $58.66 \pm 2.36^{*}$ & $104.11 \pm 8.46$ & $6.11 \pm 0.67 *$ \\
\hline & 14 & $157.225 \pm 12.15^{* *}$ & $202.71 \pm 11.99 * *, * * *$ & $60.16 \pm 3.11 * *$ & $102.21 \pm 10.20$ & $6.49 \pm 0.66^{* *}$ \\
\hline \multirow[t]{2}{*}{$\mathrm{F}$} & 7 & $71.59 \pm 6.41$ & $108.59 \pm 10.23$ & $38.35 \pm 2.41$ & $101.10 \pm 7.12$ & $4.78 \pm 1.07$ \\
\hline & 14 & $82.59 \pm 4.31^{* * *}$ & $102.62 \pm 4.52 * * *$ & $41.18 \pm 2.38$ & $104.46 \pm 5.66$ & $4.97 \pm 0.71$ \\
\hline
\end{tabular}

Data $(n=10)$ were analyzed by ANOVA + Tukey's post test

*Statistically significant differences $(P<0.01)$ in comparison with control condition at 7 days; **statistically different $(P<0.01)$ in comparison with control condition at 14 days; ***statistically significant differences $(P<0.01)$ between the two times of exposure 
animals. Moreover, after 14 days of exposition, a significant decrease was observed in worms exposed to soils from sites $\mathrm{C}$ and $\mathrm{B}$ for CAT activity and $\mathrm{C}$ and D for SOD activity, contrary to GST enzyme profile where a significant enhancement was noted for all animals, except for E site.

Exposed earthworms to a gradient of six contaminated soil for 7 and 14 days had lead in an inhibition on AChE activity, with a maximum reached in animals exposed to the highest contaminated soils (A, B, and C) after 7-day exposure. A recover in AChE activity was observed after 14 days in animals exposed to soils from B and C sites, but the AChE activity is also maintained inhibited, compared to control soil (F).

Lipid oxidative alteration was investigated by evaluating MDA accumulation (Table 3 ). This biomarker significantly increased in worms exposed to sites $\mathrm{A}, \mathrm{B}$, and $\mathrm{C}$ after the two exposure periods, being more pronounced after 14 days. The maximum MDA level was registered in animals exposed to site A after 14-day exposure with values up to $14.732 \pm 0.52 \mathrm{nmol} \mathrm{mg}$ protein ${ }^{-1}$ compared to control animals $\left(4.97 \pm 0.71 \mathrm{nmol} \mathrm{mg} \mathrm{protein}^{-1}\right)$.

Results from PCA using biomarker date in worms exposed to contaminated soil from Djebel Ressas revealed that the first axis $(53.7 \%)$ was mainly influenced by SOD and CAT while MDA, GST, and AChE mainly composed the second axis $(32.7 \%)$ (Fig. 2). These axes appeared associated with a specific worm response since the six soils were clearly separated. Indeed, the highest contaminated site $(\mathrm{A})$ is mainly characterized by a high MDA accumulation and an inhibition of $\mathrm{AChE}$

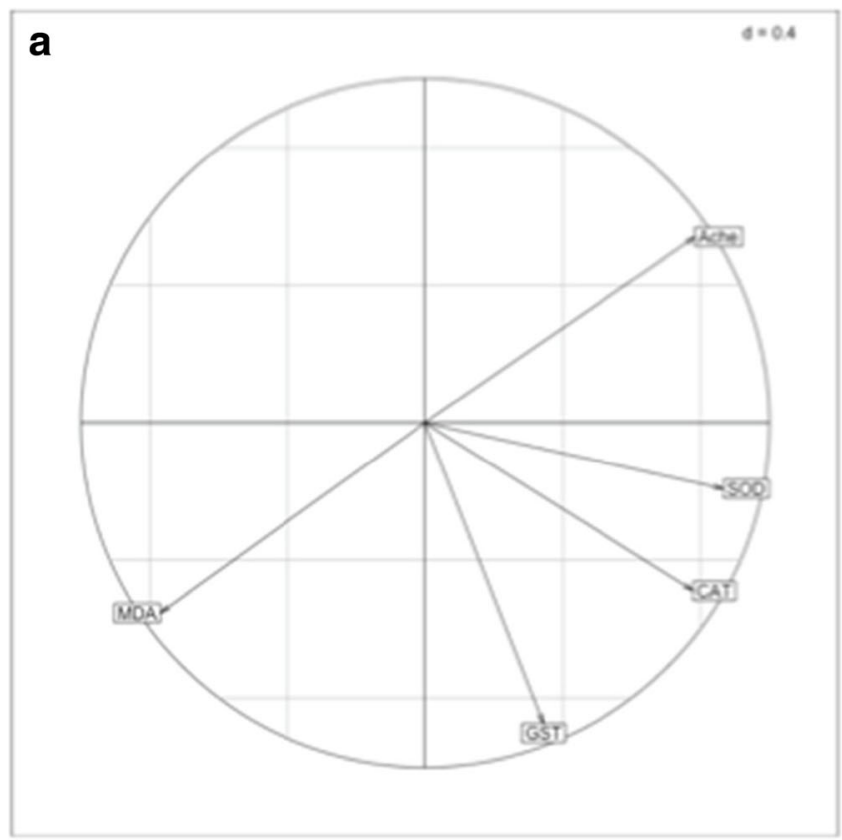

Fig. 2 PCA analysis of earthworm biomarker evolution in six polycontaminated soils at 7 and 14 days of incubation. The plot of the oxidative biomarkers (a) and the plot of the six contaminated soils (b) are represented. Sample name: First letter represents the soil, $W$ means with activity, while the sites with an intermediate contamination are characterized by a high antioxidant enzyme activity and an inhibited AChE activity. On the other hand, change in biomarker profile between the two exposure periods was observed for earthworms exposed to soils A, B, C, and F.

\section{Gene expression in $E$. andrei exposed to heavy metal-contaminated soils}

Transcriptomic data revealed significant increases in the mRNA levels of the CAT, SOD, and GST targets in worms exposed to soils from $\mathrm{C}, \mathrm{D}$, and $\mathrm{E}$ sites, compared to control animals whatever the incubation time (Table 4). For the most contaminated site (A), a significant increase was only observed in the case of GST gene after 7 days of exposure, while gene expression was negatively regulated in the other treatments. Moreover, in soil B, GST was reported to be upregulated after 7 and 14 days; CAT expression level was only upregulated after 7 days. But no regulation was observed for SOD. The mRNA levels after 7 days of exposition of the CAT and SOD in E. andrei were the highest for the soil from site C, with, respectively, $7.81 \pm 0.68$-fold and $8.77 \pm 1.62$-fold, while GST level was the highest in animals exposed to soil from the site $\mathrm{B}$ with value $14.51 \pm 0.41$.

\section{Evolution of bacterial community structure using RISA}

Evolution of bacterial community structures was compared between six sites in presence or absence of earthworms after

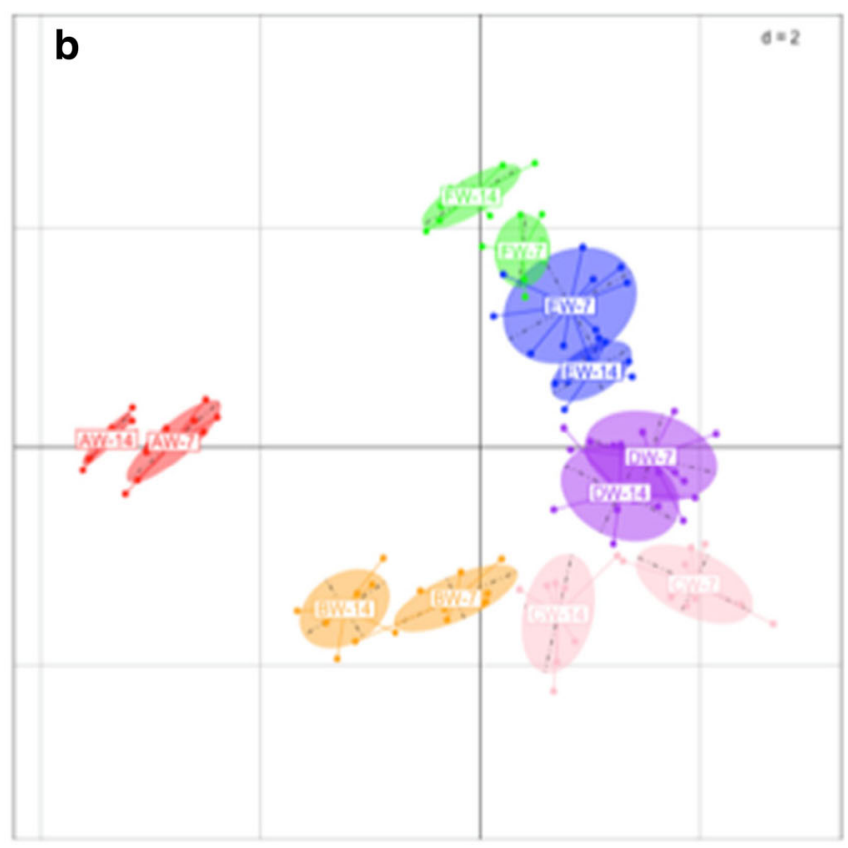

worms, and the number is the incubation time. Soil A: red ellipses, soil B: orange ellipses, soil C: purple ellipses, soil D: cyan ellipses, soil E: blue ellipses, and soil F: green ellipses 
Table 4 QPCR data of SOD, CAT, and GST targets in E. andrei after 7 or 14 days of exposition to six heavy metal-contaminated soils from the Djebel Ressas site

\begin{tabular}{lcccl}
\hline Site & Time (days) & CAT & GST & SOD \\
\hline A & 7 & $0.2 \pm 0.11$ & $3.61 \pm 0.16^{\mathrm{a}}$ & $0.42 \pm 0.16$ \\
& 14 & $0.32 \pm 0.12$ & $1.21 \pm 0.11$ & $0.38 \pm 0.13$ \\
B & 7 & $2.11 \pm 0.12^{\mathrm{a}}$ & $14.51 \pm 0.41^{\mathrm{a}}$ & $1.37 \pm 0.42$ \\
& 14 & $1.48 \pm 0.31$ & $8.24 \pm 0.12^{\mathrm{b}}$ & $0.87 \pm 0.22$ \\
$\mathrm{C}$ & 7 & $7.81 \pm 0.68^{\mathrm{a}}$ & $10.75 \pm 0.72^{\mathrm{a}}$ & $8.77 \pm 0.58^{\mathrm{a}}$ \\
& 14 & $2.32 \pm 0.31^{\mathrm{b}}$ & $3.86 \pm 0.48^{\mathrm{b}}$ & $2.63 \pm 0.21^{\mathrm{b}}$ \\
$\mathrm{D}$ & 7 & $6.44 \pm 0.44^{\mathrm{a}}$ & $7.58 \pm 1.62^{\mathrm{a}}$ & $5.28 \pm 0.74^{\mathrm{a}}$ \\
& 14 & $3.44 \pm 0.11^{\mathrm{b}}$ & $3.56 \pm 0.44^{\mathrm{b}}$ & $2.75 \pm 0.32^{\mathrm{b}}$ \\
$\mathrm{E}$ & 7 & $4.78 \pm 0.35^{\mathrm{a}}$ & $3.21 \pm 1.96^{\mathrm{a}}$ & $5.84 \pm 0.11^{\mathrm{a}}$ \\
& 14 & $2.36 \pm 0.10^{\mathrm{b}}$ & $2.88 \pm 0.71^{\mathrm{b}}$ & $2.42 \pm 0.01^{\mathrm{b}}$ \\
$\mathrm{F}$ & 7 & $1.00 \pm 0.11$ & $1.00 \pm 0.25$ & $1.00 \pm 0.01$ \\
& 14 & $1.52 \pm 0.01$ & $1.64 \pm 0.10$ & $1.68 \pm 0.01$ \\
\hline
\end{tabular}

Gene expression was performed with respect to the control condition (site F) expressed as relative quantity/fold increased and was normalized against $\beta$-actin, $18 \mathrm{~S}$, and riboS13

*Significantly different from reference condition at 7 days; **significantly different from reference condition at 14 days, $P<0.05$ threshold cycle random reallocation test according to Pfaffl et al. (2002), $n=4$

14 days of incorporation. The bacterial community structures of the soils from site A were distinct from those of the other soils as shown by PCA analysis (Fig. 3) The first axis of the PCA explains $71.9 \%$ of variance and shown a strong separation between soils from site A and the others, whether or not worms were present, especially F1 and EV1 $(P$ value $=0.001)$. The first axis showed an impact of earthworms in bacterial community structure of the less contaminated soils $\mathrm{E}$ and F. This impact is different according to the soil; this is consistent with the fact their bacterial communities are not similar at the initial stage. In site A, which is the most polluted site, the presence of $E$. andrei in the soil did not affect bacterial communities since the difference between soils with and without earthworms was not observed.

\section{Relationship between bacterial community structure and earthworm biomarkers}

In order to analyze the correlation between bacterial community structure and earthworm biomarker data, a coinertia analysis was performed (Fig. 4). The coinertia analysis indicates that the bacterial community structures and earthworm biomarkers are correlated $(P=0.001$; RV coefficient $=0.54)$. The first axis accounted for $92.9 \%$ of the explained inertia while the second axis accounted for $6.7 \% \%$ of the explained inertia (Fig. 3). The projection of inertia axes showed that sampling sites were well distributed along axis 1 which distinguishes site $\mathrm{A}$ with $\mathrm{C}$ and $\mathrm{D}$ sites (the intermediate polluted

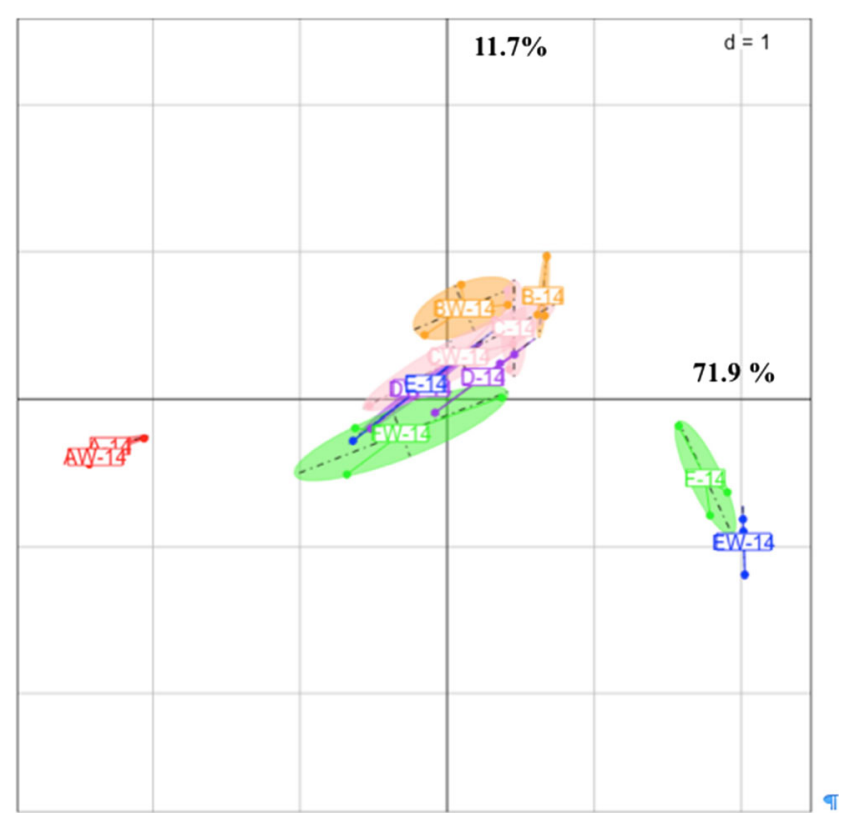

Fig. 3 PCA analysis of soil bacterial community structure in six polycontaminated Djebel Ressas soils after 14 days of incubation with or without Eisenia andrei introduction. Sample name: First letter represents the soil, $W$ means with worms, and the number is the incubation time. Soil A: red ellipses, soil B: orange ellipses, soil C: purple ellipses, sol D: cyan ellipses, sol E: blue ellipses, and soil F: green ellipses

soils in this study), while sites A, F, and E were opposite to B and $\mathrm{C}$ sites along axis 2 .

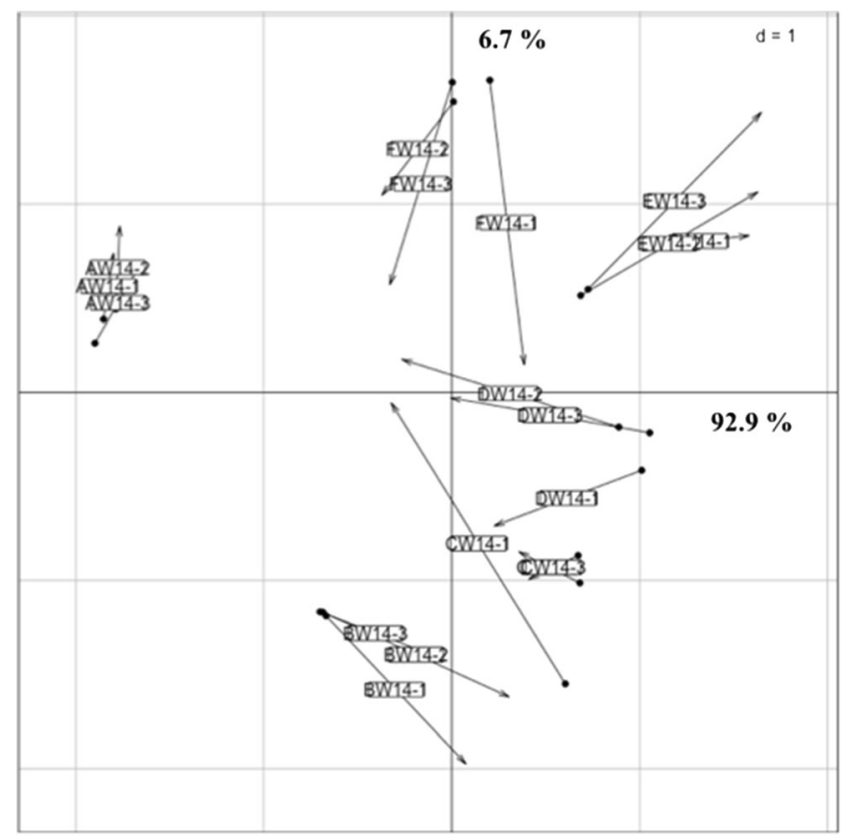

Fig. 4 Correlation between bacterial community structure and earthworm biomarkers by coinertia analysis. Sample name: First letter represents the soil, $W$ means with worms, and the first number is the incubation time and the second one the sample number. Each site is represented by two points: one corresponds to the bacterial structure and the other corresponds to the earthworm biomarker data 
The coupling of the two tables by coinertia projection showed that correlations between both datasets were very high with the most contaminated site (A), contrary to the all other sites.

\section{Discussion}

The aim of the present study was to study the relationship between the oxidative status of earthworms and the evolution of bacterial community structure in heavy metal-contaminated soils from an orphaned mine in Tunisia, Djebel Ressas mine. In order to apprehend these interactions in a context of heavy metal-polycontaminated soils ( $\mathrm{Cd}, \mathrm{Pb}$, and $\mathrm{Zn})$, E. andrei earthworms were introduced into six contaminated soils from the mine and agricultural area, constituting a contamination gradient. Firstly, the response of worms to the presence of heavy metal was analyzed at the biochemical and transcriptional levels. In a second time, impact of worm on bacterial community structure was investigated.

Extensive literature has focused on the effect of heavy metals on earthworms, but most of the experiences were conducted on artificial soils (Saint-Denis et al. 2001; Yang et al. 2012). Only few studies have been conducted in field from heavy metal-contaminated soils such as mines (Laszczyca et al. 2004; Lukkari et al. 2004). Furthermore, few studies were conducted on mining environment in Tunisia, but all of them focused on the physicochemical analyses (Ghorbel et al. 2014). The present work is, in our knowledge, the first dealing with the biological activity in soils surrounding mines in Tunisia. The originality of this work consists in the use of the earthworm E. andrei to evaluate and improve the Djebel Ressas soil quality.

Prior to the biological evaluation, the metal's loads in exposed worms performed in a parallel work of our group were considered. These data indicated an increasing pattern of worm's metal tissue concentrations along with the polymetallic gradient. Indeed, the maximum metal loads were obtained after 14 days in animals exposed to site A, with levels of $15.47 \pm 2.21,578.42 \pm 28.57,4.96 \pm 0.21$, and $275.46 \pm 28.65 \mu \mathrm{g} \mathrm{g}^{-1}$ dry weight for $\mathrm{Cd}, \mathrm{Pb}, \mathrm{Cu}$, and $\mathrm{Zn}$, respectively. Moreover, there was a significant difference in the metal loads in the worm tissues after exposure to site A and site $B$ for 7 or 14 days. In addition, bioconcentration factors (BCF) were calculated after 14 days of exposure indicating that a highest BCF value was in worms exposed to site A for 14 days. Cd showed the highest bioconcentration.

In the present study, an impact of heavy metalcontaminated soils on the oxidative status of $E$. andrei was observed. The effect was dependent on the level of heavy metal contamination. The biphasic response of the SODCAT-GST system, which acts as the key part to fight against oxygen damage and free radicals generated, reflects the gradient of heavy metal pollution, whatever the exposition time.
In fact, the higher response was observed in the soil with intermediate contamination (site $\mathrm{C}$ ) and an inhibition of these enzymes occurred in the mine spoils (site A), which are the more contaminated one. A similar response was found in enzymes involved in oxidative stress in three earthworm species in a mine with the same kind of contamination gradient (Laszczyca et al. 2004). At low concentrations, Cd could increase CAT and SOD activity and inhibit them at high concentrations (Zhang et al. 2009); this could explain the biphasic response observed in our study. However, it is important to underline the fact that the direct relationship between enzymatic activities and heavy metals concerns only the available fraction of the later, and thus, more in-depth analysis of metal speciation and bioavailability is needed to establish a clear picture of this interaction.

The ability of a stressed organism to adjust its cellular processes via transcriptional control can allow it to cope with the alteration of cellular functions and to avoid cellular damage that could also lead to death. Interestingly, in this study, we had observed that there was a similarity response of antioxidant enzymes and their relative gene expression. Indeed, compared to antioxidant enzyme profiles, an enhancement of enzyme activities and gene expressions was observed simultaneously for the intermediate contaminated sites (C, D, and E). However, for site A (the most contaminated soil), this relation was observed only in the case of GST where enzyme activity and related gene expression are stimulated after 7 days of exposure. However, the impairment of cellular function due to extreme heavy metal loads may explain the alteration of the gene expression regulation of key genes in cell defense mechanisms such as antioxidant enzymes.

The presence of heavy metals in mine soils had inhibited the $\mathrm{AChE}$ in the most contaminated sites (A, B, and $\mathrm{C}$ ). In the literature, the response of $\mathrm{AChE}$ activity to metal is inconstant as well; activation or inhibition was observed (Beauvais et al. 2001; Zatta et al. 2002; Romani et al. 2003; Frasco et al. 2005).

Application of multiple biomarkers to evaluate the effect of complex pollutants is prevalent in recent years and becomes a suitable line of evidence for assessing biological effects from pollution and the evaluation of its environmental impacts (Hyne and Maher 2003; Weeks et al. 2004; SanchezHernandez 2006; Rodriguez-Castellanos and SanchezHernandez 2007). In soil from Djebel Ressas, heavy metal affects $E$. andrei earthworm as shown by biomarker analysis. This impact on $E$. andrei could have negative consequences on his functioning in the soil.

Earthworms, as ecosystem engineers, establish a close relationship with soil bacterial communities to exploit soil organic matter. In the present study, we had hypothesize that earthworms influence bacterial community structure in soils from Djebel Ressas.

In order to follow the bacterial community structure, the automated ribosomal intergenic spacer analysis (ARISA) 
fingerprinting method was used. This method has been successfully used for monitoring microbial communities in complex environments (Héry et al. 2003). The impact of E. andrei on bacterial community structure is observed in heavy metalcontaminated soil from Djebel Ressas. Nevertheless, the evolution of bacterial community structure is subject to the level of contamination of the soil; the major impact was observed in the less contaminated soils. Similar observations were obtained in soil artificially contaminated by arsenic in presence of Allolobophora molleri (Tejada et al. 2013). Moreover, previous studies showed that earthworm may increase or conversely not change the abundance of microbial biomass in soils (Sampedro et al. 2006; Sampedro and Whalen 2007; Koubova et al. 2015). Recent reports indicated that earthworms influence the degree of functional response of microbial communities and affected the degree of utilization of substrates as indicated by Biolog profiles (Koubova et al. 2015).

The fact that earthworms make a major contribution to decomposition in ecosystems could explain the evolution of bacterial community structure. The burrow activity and cast production of earthworms produce mucus and other substances that modify the soil physicochemical environment. These changes may affect bacterial community in terms of changes in the relative abundance of different taxa, the emergence of some, or potentially the extinction of others. Some bacteria are not adapted to the drilosphere or earthworm gut environments (Nechitaylo et al. 2010; Bernard et al. 2012; Huang et al. 2014). In soil, the earthworm casts stimulate bacterial community activities and transfers of bacteria between casts and soils were observed (Aira et al. 2010; Jirout and Pizl 2014). All these biological and edaphic parameters could drive bacterial community diversity in the soils of Djebel Ressas. The nature of earthworm's impact on bacterial community was analyzed in various environments Aira and Domínguez 2009; Aira et al. 2009; Gomez-Brandon et al. 2011; Gomez-Brandon et al. 2010). Kinds of substrates or worm species have an impact on the interaction between worms and bacterial communities (Koubava et al. 2015; Aira and Domínguez 2009). Each earthworm species is characterized by a particular mode of food selection, ingestion, digestion, assimilation, movement, and a specific bacterial microbiome. Therefore, each worm species interacts differently on bacterial community structure and activity (Curry and Schmidt 2007; Lavelle 2002; Monroy et al. 2008; Thakuria et al. 2010). However, there is currently dearth of information on the mechanisms that determine the interaction bacteria-earthworms. In this study, the hypothesis of the contribution of the earthworm oxidative status in this relationship is made for the first time. To test this hypothesis, a multivariate analysis method (coinertia) analysis was performed and a correlation between earthworm oxidative status biomarkers and bacterial community structure was observed. This finding demonstrated that the earthworm functioning and bacteria response to their borrowing activity are significantly dependent of worm oxidative status. The more significant correlation was observed in the mine spoils (A), which have the higher heavy metal concentrations. This suggests that earthworm activity is dependent on antioxidant enzymes and lipid peroxidation, which are involved in the mechanisms of ROS detoxification. That means that for soil A, earthworms do not influence bacterial community structure because their oxidative status was deteriorated by the presence of heavy metal. Also, presence of earthworms can influence heavy metal speciation in soils. Indeed, several studies indicated that earthworms impacted the mobility of metals in soils (Lukkari et al. 2006; Sizmur et al. 2011) by reducing the available fraction (Liu et al. 2005; Zorn et al. 2005; Li et al. 2009). It is also known that the change on heavy metal speciation is an important factor determining the diversity and activity of bacterial communities in soils. This can let us hypothesize that earthworms reduce the availability of heavy metals in the less contaminated Djebel Ressas soils, which lead up to the change of bacterial community structure.

In the Djebel Ressas context of heavy metal contamination, the worm health and the bacterial community structure are interdependent. Indeed, the health of the earthworms is impacted by the concentration in heavy metals, which alters their oxidative status. These modifications involve changes of their activities, like organic matter degradation, and therefore, their impact on the structure of the bacterial communities is altered.

\section{Conclusion}

These results provide an insight into the mechanisms and factors influencing the earthworms and bacteria interactions, and should be very useful for the design of management practices for sustainable agriculture. However, our results suggest that bioremediation using earthworms is more appropriate to agricultural soils than to mine spoils. In order to better understand the relationships between earthworms and bacteria communities, future studies, using next-generation sequencing, will be necessary to identify changes in bacterial community relative abundance at the species level in the presence of $E$. andrei in Djebel Ressas mines.

Acknowledgements This work was supported by funds from the "Ministère de l'Enseignement Supérieur et de la Recherche Scientifique; UR04A6R05. Biochimie et Toxicologie Environnementale" and by the Mistral Project "Them SICMED". This work was also supported by funds from the laboratory "AMPERE Ecole Centrale de Lyon." 


\section{References}

Adriano D (2001) Cadmium, trace elements in terrestrial environments: biogeochemistry, bioavailability, and risks of metals. Springer Verlag, New York, pp 263-314

Aira M, Domínguez J (2009) Microbial and nutrient stabilization of two animal manures after the transit through the gut of the earthworm Eisenia fetida (Savigny, 1826). J Hazard Mater 161:1234-1238. doi: 10.1016/j.jhazmat.2008.04.073

Aira M, McNamara NP, Piearce TG, Domínguez J (2009) Microbial communities of Lumbricus terrestris L. middens: structure, activity, and changes through time in relation to earthworm presence. J Soils Sediment 9:54-61. doi:10.1007/s11368-008-0055-8

Aira M, Lazcano C, Gómez-Brandón M, Domínguez J (2010) Ageing effects of casts of Aporrectodea caliginosa on soil microbial community structure and activity. Appl Soil Ecol 46:143-146. doi:10. 1016/j.apsoil.2010.06.001

Banni M, Negri A, Boussetta H, Viarengo A, Dondero F (2011) Gene expression rhythms in the mussel Mytilus galloprovincialis (Lam.) across an annual cycle. PLoS One 6(5):e18904. doi:10.1371/ journal.pone.0018904

Beauvais SL, Jones SB, Parris JT, Brewer SK, Little EE (2001) Cholinergic and behavioral neurotoxicity of carbaryl and cadmium to larval rainbow trout (Oncorhynchus mykiss). Ecotox Environ Safe 49(1):84-90. doi:10.1006/eesa.2000.2032

Bernard L, Chapuis-Lardy L, Razafimbelo T, Razafindrakoto M, Pablo AN, Legname E, Poulain J, Bruls T, O'Donohue M, Brauman A, Chotte JL, Blanchart E (2012) Endogeic earthworms shape bacterial functional communities and affect organic matter mineralization in a tropical soil. The ISME Journal 6:213-222. doi:10.1038/ismej. 2011.87

Bradford MM (1976) A rapid and sensitive method for the quantitation of microgram quantities of protein utilizing the principle of proteindye binding. AnalBiochem 72(1-2):248-254

Bradl H (2002) Heavy metals in the environment: origin, interaction and remediation. London

Brown GG (1995) How do earthworms affect microfloral and faunal community diversity? J Plant Soil 170:209-231

Carson PL (1980) Recommended potassium test. P. 12-13. In W.C. Dahnke. (ed.). Recommended chemical soil test procedures for the North Central Region. North Central Region Publication 221 (revised). N.D. Agri. Exp. Stn., Fargo, N.D.

Celo V, Babi D, Baraj B, Cullaj A (1999) An assessment of heavy metal pollution in the sediments along the Albanian Coast. J Water Air SoilPollut 111:235-250

Chang LW, Magos L, Suzuki T (1996) Toxicology of metals. CRC Press, Boca Raton

Chomczynski P, Sacchi N (1987) Single-step method of RNA isolation by acid guanidinium thiocyanate-phenol-chloroform extraction. Anal Biochem 162:156-159

Claiborne A (1985) Catalase activity. In: Greenwald RA (ed) Handbook of methods for oxygene radical research. CRC Press, BocaRaton, pp 283-284

Cottenie A, Camerlynck R, Verloo M, Dhaese A (1980) Fractionation and determination of trace elements in plants, soils and sediments. Pure App Chem 52(1):45-53

Crouch RK, Gandy SE, Kimsey G, Galbraith RA, Galbraith GM, Buse MG (1981) The inhibition of islet superoxide dismutase by diabetogenic drugs. Diabetes 30:235-241

Curry JP, Schmidt O (2007) The feeding ecology of earthworms - a review. Pedobiologia 50:463-477

Doledec S, Chessel D (1994) Co-inertia analysis: an alternative method for studying species-environment relationships. Freshw Biol 31: 277-294
Dray S, Chessel D, Thioulouse J (2003) Co-inertia analysis and the linking of ecological data tables. J Ecology 84(11):3078-3089

Egert M, Marhan S, Wagner B, Scheu S, Friedrich MW (2004) Molecular profiling of $16 \mathrm{~S}$ rRNA genes reveals diet-related differences of microbial communities in soil, gut, and casts of Lumbricus terrestris $L$ (Oligochaeta: Lumbricidae) FEMS. Microbio Ecol 48:187-197. doi:10.1016/j.femsec.2004.01.007

Ellman GL, Courtney KD, Andres V Jr, Feather-stone RM (1961) A new and rapid colorimetric determination of acetylcholinesterase activity. BiochemPharmacol 7:88-95

Fergusson JEE (1990) The heavy elements: chemistry, environmental impact and health effects. Pergamon Press, Oxford

Frasco MF, Fournier D, Carvalho F, Guilhermino L (2005) Do metals inhibit acetylcholinesterase (AChE)? Implementation of assay conditions for the use of AChE activity as a biomarker of metal toxicity. Biomarkers 10(5):360-375

Gerard-Monnier D, Erdelmeier I, Regnard K, Mozehenry N, Yadan JC, Chau-dierel J (1998) Reactions of 1-methyl-2-phenylindole with malondialdehyde and 4-hydroxyalkenals analytical applications to a colorimetric assay of lipid peroxidation. Chem Res Toxicol 11: $1176-1183$

Ghorbel M, Munoz M, Solmon F (2014) Health hazard prospecting by modeling wind transfer of metal-bearing dust from mining waste dumps: application to Jebel Ressas $\mathrm{Pb}-\mathrm{Zn}-\mathrm{Cd}$ abandoned mining site (Tunisia). Environ Geochem Health 36:935-951

Gomez-Brandon M, Lazcano C, Lores M, Domınguez J (2010) Detritivorous earthworms modify microbial community structure and accelerate plant residue decomposition. Appl Soil Ecol 44: 237-244. doi:10.1016/j.apsoil.2009.12.010

Gomez-Brandon M, Aira M, Lores M, Domınguez J (2011) Changes in microbial community structure and function during vermicomposting of pig slurry. BioresourTechnol 102:4171-4178. doi:10.1016/j.biortech.2010.12.057

Gong P, Siciliano SD, Srivastava S, Greer CW, Sunahara GI (2002) Assessment of pollution induced microbial community tolerance to heavy metals in soil using ammonia-oxidizing bacteria and biolog assay. Hum Ecol Risk Assess 8:1067-1081

Habig WJ, Pabst MJ, Jacoby WB (1974) Glutathione S-transferase, the first enzymatic step in mercapturic acid formation. J BiolChem 249: 7130-7139

Hattab S, Boughattas I, Boussetta H, Viarengo A, Banni M, Sforzinic S (2015) Transcriptional expression levels and biochemical markers of oxidative stress in the earthworm Eisenia andrei after exposure to 2, 4-dichlorophenoxyacetic acid (2,4-D). Ecotox Environ Safe 122: 76-82

Héry M, Nazaret S, Jaffré T, Normand P, Navarro E (2003) Adaptation to nickel spiking of bacterial communities in neocaledonian soils. Environ Microbiol 5(1):3-12

Hu CW, Cui YB, Chen J, Yang IY (2010) Toxicological effects of TiO2 and $\mathrm{ZnO}$ nanoparticles in soil on earthworm Eisenia fetida. Soil Biol Biochem 42:586-591

Huang K, Li F, Wei Y, Fu X, Chen X (2014) Effects of earthworms on physicochemical properties and microbial profiles during vermicomposting of fresh fruit and vegetable wastes. Bioresour Technol 170:45-52

Hyne RV, Maher WA (2003) Invertebrate biomarkers: links to toxicosis that predict population decline. Ecotoxicol Environ Saf 54:366-374

Jirout J, Pizl V (2014) Effects of the endemic earthworm Allolobophora hrabei (Cernosvitov, 1935) on soil microbial communities of steppe grasslands. Soil BiolBiochem 76:249-256

Jusselme D, Polyb F, Lebeauc T, Rouland-lefèvrea C, Miambid E (2015) Effects of earthworms on the fungal community and microbial activity in root-adhering soil of Lantana camara during phytoextraction of lead. Appl Soil Ecol 96:151-158 
Kenarova A, Radeva G (2010) Inhibitory effects of total and water soluble concentrations of heavy metals on microbial dehydrogenase activity. C R Acad Bulg Sci 63(7):1029-1034

Kenarova A, Radeva G, Traykov I, Boteva S (2014) Community level physiological profiles of bacterial communities inhabiting uranium mining impacted sites. Ecotox Environ Saf 100:226-232

Koubova A, Chronakova A, Pizl V, Sanchez-Monedero AM, Elhottova D (2015) The effects of earthworms Eisenia spp. on microbial community are habitat dependent. EuropJ Soil Biology 68:42-55

Kozdrój J, van Elsas JD (2001) Structural diversity of microorganisms in chemically perturbed soil as assessed by molecular and cytochemical approaches. J Microbiol Methods 43:197-212

Kristufek V, Ravasz K, Pizl V (1992) Changes in diversity of bacteria and microfungi during gut transit in Lurribricus rubellus and Aporrectodea caliginosa (Ologichaeta: Lumbricidae). Soil Biol Biochem 24(1499):1500

Laszczyca P, Augustyniak M, Babczynska A, Bednarska K, Kafel A, Migula P, Wilczek G, Witas I (2004) Profiles of enzymatic activity in earthworms from zinc, lead and cadmium polluted areas near Olkusz (Poland). Environ Int 30:901-910

Lavelle P (1997) Faunal activities and soil processes: adaptive strategies that determine ecosystem function. AdvEcol Res 27:93-132

Lavelle P (2002) Functional domains in soils. Ecol Res 17:441-450

Li L, Wu J, Tian G, Xu Z (2009) Effect of the transit through the gut of earthworm (Eisenia fetida) on fractionation of $\mathrm{Cu}$ and $\mathrm{Zn}$ in pig manure. J Hazard Mat 167:634-640

Liu X, Hu C, Zhang S (2005) Effects of earthworm activity on fertility and heavy metal bioavailability in sewage sludge. Environ Int 31: 874-879

Lukkari T, Taavitsainen M, Soimasuo M, Oikari A, Haimi J (2004) Biomarker responses of the earthworm Aporrectodea tuberculata to copper and zinc exposure: differences between populations with and without earlier metal exposure. Environ Pollut 129:377-386

Lukkari T, Teno S, Vaeisaenen A, Haimi J (2006) Effects of earthworms on decomposition and metal availability in contaminated soil: microcosm studies of populations with different exposure histories. Soil Biolo Biochem 38:359-370

Monroy F, Aira M, Domínguez J (2008) Changes in density of nematodes, protozoa and total coliforms after transit through the gut of four epigeic earthworms (Oligochaeta). Appl Soil Ecol 39:127-132

Moore J, Berlow EL, Coleman DC, de Ruiter PC, Dong Q, Hastings A, Johnson NC, McCann KS, Melville K, Morin PJ, Nadelhoffer K, Rosemond AD, Post DM, Sabo JL, Scow KM, Vanni MJ, Wall DH (2004) Detritus, trophic dynamics and biodiversity. Ecol Lett 7:584 600

Navarro E, Fabrègue O, Scorretti R, Reboulet J, Simonet P, Dawson L, Demanèche D (2015) RisaAligner software for aligning fluorescence data between Agilent 2100 Bioanalyzer chips: application to soil microbial community analysis. BioTechniques 59:347-358. doi:10.2144/000114363

Nechitaylo TY, Yakimov MM, Godinho M, Timmis KN, Belogolova E, Byzov BA, Kurakov AV, Jones DL, Golyshin PN (2010) Effect of the earthworms Lumbricus terrestris and Aporrectodea caliginosa on bacterial diversity in soil. Microb Ecol 59(3)

Negri A, Oliveri C, Sforzini S, Mignione F, Viarengo A, Banni M (2013) Transcriptional response of the mussel Mytilus galloprovincialis (Lam.) following exposure to heat stress and copper. PLoS One 8(6): 668802

OECD (1984) Guidelines for the testing of chemicals no. 207. Earthworm acute toxicity. Organization for Economic Cooperation and Development, Paris

Olsen S, Cole C, Watanabe F, Dean L (1954) Estimation of available phosphorus in soils by extraction with sodium bicarbonate. USDA Circular Nr 939, US Gov Print Office, Washington, DC
Orazova MK, Dobrovol'skaya TG, Semenova TA, Zvyagintsev DG (2005) The bacterial-fungal complexes in litter, soil, and earthworm coprolites. Eurasian Soil Sci 38:860-863

Pfaffl MW, Horgan GW, Dempfle L (2002) Relative expression software tool (REST) for group wise comparison and statistical analysis of relative expression results in real-time PCR. Nucl Acids Res 30(9): $30-36$

Ramakrishnan B, Megharaj M, Sethunathan N, Naidu R (2011) Mixture of environmental pollutants: effects on microorganisms and their activities in soils. Rev Environ Contam Toxic 211:63-120

Ranjard L, Poly F, Lata JC, Mougel C, Thioulouse J, Nazaret S (2001) Characterization of bacterial and fungal soil communities by automated ribosomal intergenic spacer analysis fingerprints: biological and methodological variability. Appl Environ Microb 67:4479-4487

Rayment GE, Higginson FR (1992) Australian laboratory handbook of soil and water chemical methods. Inkata Press, Port Melbourne

Rodriguez-Castellanos L, Sanchez-Hernandez JC (2007) Earthworm biomarkers of pesticide contamination: current status and perspectives. J Pest Sci 32:360-371

Romani R, Antognelli C, Baldracchini F, De Santis A, Isani G, Giovannini E, Rosi G (2003) Increased acetylcholinesterase activities in specimens of Sparus auratus exposed to sublethal copper concentrations. Chem Int 145(3):321-329

Saint-Denis M, Narbonne JF, Arnaud C, Ribera D (2001) Biochemical responses of the earthworm Eisenia fetida andrei exposed to contaminated artificial soil: effects of lead acetate. Soil Biol Biochem 33:395-404

Sampedro L, Whalen JK (2007) Changes in the fatty acid profiles through the digestive tract of the earthworm Lumbricus terrestris L. Appl Soil Ecol 35:226e236

Sampedro L, Jeannotte R, Whalen JK (2006) Trophic transfer of fatty acids from gut microbiota to the earthworm Lumbricus terrestris $\mathrm{L}$. Soil Biol Biochem 38:2188e2198

Sanchez-Hernandez JC (2006) Earthworms biomarkers in ecological risk assessment. Rev Environ ContamToxicol 188:85-126

Schreck E, Geret F, Gontier L, Treilhou M (2008) Neurotoxic effect and metabolic responses induced by a mixture of six pesticides on the earthworm Aporrectodea caliginosa nocturna. Chemosphere 71(10): 1832-1839

Sforzini S, Moore MN, Boeri M, Bencivenga M, Viarengo A (2015) Effects of PAHs and dioxins on the earthworm Eisenia andrei: a multivariate approach for biomarker interpretation. Environ Pollut 196:60-71

Sizmur T, Palumbo-Roe B, Hodson ME (2011) Impact of earthworms on trace element solubility in contaminated mine soils amended with green waste compost. Environ Pollut 159:1852-1860

Souissi R, Souissi F, Chakroun HK, Bouchardon JL (2013) Mineralogical and geochemical characterization of mine tailings and $\mathrm{Pb}, \mathrm{Zn}$, and $\mathrm{Cd}$ mobility in a carbonate setting (Northern Tunisia). Mine Water and the Enviro 32(1):16-27

Tack FMG, Verloo MG (1995) Chemical speciation and fractionation in soil and sediment heavy metal analysis: a review. Int J Environ An Ch 59(2):225-238

Tejada M, Gomez I, Hernandez T, Garcia C (2013) Influence of the activity of Allobophora molleri in microbial activity and metal availability of arsenic-polluted soils. Arch Environ Contam Toxicol 65(3):449-457. doi:10.1007/s00244-013-9914-4

Thakuria D, Schmidt O, Finan D, Egan D, Doohan MF (2010) Gut wall bacteria of earthworms: a natural selection process. The ISME Journal 4:357-366

Thioulouse J, Dray S (2007) Interactive multivariate data analysis in R with the ade4 and ade4TkGUI packages. J of StatSoftw 22(5):1-14

Tsyusko OV, Hardas SS, Shoults-Wilson WA, Starnes CP, Joice G, Butterfield DA, Unrine JM (2012) Short-term molecular-level effects of silver nanoparticle exposure on the earthworm, Eisenia fetida. Environ Pollut 171:249-255 
Vig K, Megharaj M, Sethunathan N, Naidu R (2003) Bioavailability and toxicity of cadmium to microorganisms and their activities in soil: a review. Adv Environ Res 8:121-135

Wang S, Shi X (2001) Molecular mechanisms of metal toxicity and carcinogenesis. Mol Cell Biochem 222:3-9

Weeks JM, Spurgeon DJ, Svendsen C, Hankard PK, Kammenga JEK, Dallinger R, Köhler HR, Simonsen V, Scott-Fordsmand J (2004) Critical analysis of soil invertebrate biomarkers: a field case study in Avonmouth, UK. Ecotoxicology 13:817-822

Yang X, Song S, Ackland ML, Liu Y, Cao X (2012) Biochemical responses of earthworm Eisenia fetida exposed to cadmiumcontaminated soil with long duration. Bull Environ ContamToxicol 89:1148-1153
Zatta P, Ibn-Lkhayat-Idrissi M, Zambenedetti P, Kilyen M, Kiss T (2002) In vivo and in vitro effects of aluminum on the activity of mouse brain acetylcholinesterase. Brain Res Bull 59(1):41-45

Zhang GL, Yang FG, Zhao YG, Zhao WJ, Yang JL, Gong ZT (2005) Historical change of heavy metals in urban soils of Nanjing, China during the past 20 centuries. Environ Int 31:913-919

Zhang S, Hu F, Li H, Li X (2009) Influence of earthworm mucus and amino acids on tomato seedling growth and cadmium accumulation. Environ Pollut 157:2737-2742

Zorn MI, Van Gestel CAM, Eijsackers H (2005) The effect of Lumbricus rubellus and Lumbricus terrestris on zinc distribution and availability in artificial soil columns. Biol Fert Soils 41:212-215 